\title{
TaqI, FokI, and ApaI Polymorphisms in the Vitamin D Receptor in Behçet's Disease in Turkish Population
}

\author{
Gaye Erten, ${ }^{1}$ Muhammed Kalkan, ${ }^{2}$ Sema Bilgiç Gazioğlu, ${ }^{1}$ Nilgun Akdeniz, \\ Elif Ozkok, ${ }^{3}$ and Burcak Vural ${ }^{2}$ \\ ${ }^{1}$ Department of Immunology, Aziz Sancar Institute of Experimental Medicine, Istanbul University, Istanbul, Turkey \\ ${ }^{2}$ Department of Genetics, Aziz Sancar Institute of Experimental Medicine, Istanbul University, Istanbul, Turkey \\ ${ }^{3}$ Department of Neuroscience, Aziz Sancar Institute of Experimental Medicine, Istanbul University, Istanbul, Turkey \\ Correspondence should be addressed to Gaye Erten; gerten@istanbul.edu.tr
}

Received 12 July 2016; Revised 4 August 2016; Accepted 9 August 2016

Academic Editor: Hubertus Himmerich

Copyright (C) 2016 Gaye Erten et al. This is an open access article distributed under the Creative Commons Attribution License, which permits unrestricted use, distribution, and reproduction in any medium, provided the original work is properly cited.

\begin{abstract}
Objectives. In our study we aimed to determine VDR gene polymorphisms in patients with Behçet's disease (BD) and neuro-Behçet's disease (NBD) in Turkish population. Methods. PBL obtained from 37 patients with BD, 21 patients with NB, and 30 healthy controls were investigated. Genomic DNA was extracted from whole blood using the QIAamp Blood Kit. VDR ApaI (rs7975232), VDR FokI (rs2228570), and VDR TaqI (rs731236) genotyping was performed by real-time polymerase chain reaction with SimpleProbe melting-curve analysis. Results. The allelic and genotype distributions of FokI and TaqI polymorphisms were not different among Behçet's disease, neuro-Behçet's disease, and control subjects in Turkish population ( $p>0.05)$. Only the frequency of ApaI A allele in control is higher than that in $\mathrm{BD}$ (60\% versus 38.5\%), and the $p$ value is 0.014 , but the power is not enough to conclude that ApaI A allele is protective in BD in our study. Taken together, we found no significant differences between the BD, NBD, and control groups regarding the distribution of ApaI, TaqI, and FokI genotype and alleles frequencies. Conclusions. Future studies with larger patients' numbers may show differences between VDR polymorphisms and Behçet's disease.
\end{abstract}

\section{Introduction}

Behçet's disease $(\mathrm{BD})$ is an autoinflammatory vasculitis described by a Turkish dermatologist, Behçet [1]. BD, also called Silk Road disease, is characterized by recurrent oral aphthous ulcers, genital ulcers, and uveitis [2]. Lately, BD has been classified as a mixed-pattern disease (in between monogenic autoinflammatory and autoimmune disorders) because of the human leukocyte antigen- (HLA-) B* 51 association [3].

Central nervous system (CNS) involvement, or neuroBehçet's disease (NBD), develops in $5-10 \%$ of BD patients and generally affects the brain parenchyma and less frequently the brain vessels and meninges [4]. The cerebral parenchymal lesions are mainly composed of mononuclear and neutrophilic infiltrates [5]. In addition to genetic and environmental factors, vitamin D is known to play important role in the pathogenesis of Behçet's disease via immunologic mechanisms like $\mathrm{T}$ cell subsets, Treg cells, and intracytoplasmic cytokines expression [6]. Lower serum vitamin $\mathrm{D}$ levels were detected in patients with active $\mathrm{BD}$ $[6,7]$. Vitamin $\mathrm{D}$ is primarily produced by ultraviolet irradiation of 7-dehydrocholesterol, but this primary form is metabolically inactive and has to be transformed to 25hydroxyvitamin D3 in the liver followed by the formation of $1 \alpha, 25$-dihydroxyvitamin D3 in kidneys [8]. From an immunologic viewpoint, vitamin $\mathrm{D}$ is known to function by binding to its receptors (VDR) on immune cells like T lymphocytes and antigen presenting cells. Vitamin D suppresses B lymphocyte proliferation, differentiation, and antibody secretion [9]. It also has a negative effect on $\mathrm{T}$ lymphocyte proliferation but induces regulatory $\mathrm{T}$ cell production $[10,11]$. The inhibitory effect of VitD3 on the Th17 and Th1 response was shown to be mediated via $\mathrm{T}$ cells and dendritic cells in patients with $\mathrm{BD}$ [12]. Vitamin D is implicated to affect endothelial functions, and replacement of vitamin $\mathrm{D}$ has been 
shown to have favorable effects on endothelial function [13]. Another study performed in 41 patients with $\mathrm{BD}$ suggested that the inflammation in BD was triggered through TLR2 and TLR4 and that vitamin D might be used as a therapeutic option for modulation of TLR2 and TLR4 expression of monocytes in $\mathrm{BD}$ [14].

The gene encoding VDR is located on chromosome 12q [15]. FokI (rs10735810), BsmI (rs1544410), TaqI (rs731236), and ApaI (rs7975232) polymorphisms are shown to play possible role in many diseases like cancer, infections, autoimmunity, allergy, and inflammation [16-20]. In our study, we aimed to determine VDR gene polymorphisms (FokI (rs2228570) (rs10735810), TaqI (rs731236), and ApaI (rs7975232)) in patients with BD and NBD in Turkish population.

\section{Materials and Methods}

2.1. Patients and Controls. PBL obtained from 37 patients with $\mathrm{BD}$ attending the Division of Rheumatology of Istanbul Faculty of Medicine and 21 patients with NB attending the Division of Rheumatology of Istanbul Faculty of Medicine, Istanbul University, were included in the study.

All patients fulfilled the diagnostic criteria of the International Study Group for BD [21]. Thirty controls DNA were provided by healthy blood donors with no known medical problems employed in the same hospital.

Patients gave informed consents, according to the principles of the Helsinki Declaration. The protocol used in the study was approved by the Local Ethical Committee of the Istanbul Medical Faculty, Istanbul University.

2.2. DNA Isolation and Genotyping. Genomic DNA was extracted from whole blood using the QIAamp Blood Kit (Qiagen, Inc.). VDR ApaI (rs7975232), VDR FokI (rs2228570), and VDR TaqI (rs731236) genotyping was performed by real-time polymerase chain reaction (RT-PCR, LightCycler, Roche) with SimpleProbe (TIB MOLBIOL) melting-curve analysis.

2.3. Statistical Analysis. Statistical analyses were performed using SPSS 21 (SPSS Inc., USA). The frequency of alleles and genotypes of VDR gene ApaI, FokI, and TaqI polymorphisms were analyzed by chi-square test. Hardy-Weinberg equilibrium (HWE) was determined by goodness-of-fit test. Differences were considered statistically significant at a $p$ value $<0.05$.

\section{Results}

We studied the FokI, ApaI, and TaqI polymorphisms in 37 patients with $\mathrm{BD}, 21$ patients with NBD, and 30 healthy controls. The Hardy-Weinberg principle was met in all groups.

Table 1 summarizes the distribution of genotype and alleles frequencies of VDR SNPs in patients with BD and control subjects. Table 2 shows the distribution of genotype and alleles frequencies of VDR SNPs in patients with NBD
TABLE 1: Distribution of genotype and alleles frequencies of VDR SNPs in Behçet's disease and control subjects.

\begin{tabular}{lccc}
\hline & Controls $n(\%)$ & Behçet's disease & $p$ value \\
\hline ApaI genotype & & & \\
AC & $10(33.3)$ & $15(42.9)$ & 0.431 \\
AA & $13(43.3)$ & $6(17.1)$ & 0.021 \\
CC & $7(23.4)$ & $14(40.0)$ & 0.152 \\
HWE & & & \\
$\quad \chi^{2}$ & 2.80 & 0.319 & \\
$\quad p$ value & 0.0942 & 0.571 & \\
\hline ApaI alleles & & & \\
A & $36(60)$ & $27(38.5)$ & 0.014 \\
C & $24(40)$ & $43(61.5)$ & 0.921 \\
\hline TaqI genotype & & & 0.294 \\
CT & $11(36.7)$ & $14(37.8)$ & \\
TT & $13(43.3)$ & $19(51.4)$ & 0.964 \\
CC & $6(20)$ & $4(10.8)$ & \\
HWE & & & \\
$\quad \chi^{2}$ & 1.511 & 0.329 & \\
$\quad p$ value & 0.218 & 0.565 & \\
\hline TaqI alleles & & & \\
C & $23(38.3)$ & $22(29.8)$ & \\
T & $37(61.7)$ & $52(70.2)$ & 0.29 \\
\hline FokI genotype & & & \\
CT & $12(40)$ & $0.143(54.4)$ & \\
TT & $15(50)$ & & \\
CC & $3(10)$ & & \\
HWE & 0.068 & & \\
$\quad \chi^{2}$ & 0.794 & & \\
T value & & & \\
C & & & \\
\hline
\end{tabular}

Differences were considered statistically significant at a $p$ value $<0.05$.

and control subjects, and Table 3 reports the distribution of genotype and alleles frequencies of VDR SNPs in all patients (BD and NBD) and control subjects.

The distribution of ApaI genotypes was $33.3 \%$ for AC, $43.3 \%$ for $\mathrm{AA}$, and $23.4 \%$ for $\mathrm{CC}$ in controls; $42.9 \%$ for $\mathrm{AC}$, $17.1 \%$ for $\mathrm{AA}$, and $40 \%$ for CC in patients with $\mathrm{BD}$; and $42.9 \%$ for $\mathrm{AC}, 33.3 \%$ for $\mathrm{AA}$, and $23.8 \%$ for CC in patients with NBD (Tables 1 and 2). Only the frequency of ApaI A allele in control is higher than that in $\mathrm{BD}(60 \%$ versus $38.5 \%)$, and the $p$ value is 0.014, but the power is not enough to conclude that ApaI A allele is protective in $\mathrm{BD}$ in our study.

The distribution of TaqI genotypes was $36.7 \%$ for CT, $43.3 \%$ for TT, and $20 \%$ for CC in controls; $37.8 \%$ for CT, $51.4 \%$ for TT, and $10.8 \%$ for CC in patients with $\mathrm{BD}$; and $47.6 \%$ for CT, $38.1 \%$ for TT, and $14.3 \%$ for CC in patients with NBD (Tables 1 and 2). The allelic and genotype distributions of TaqI polymorphisms were not different $(p>0.05)$.

The distribution of FokI genotypes was $40 \%$ for CT, $10 \%$ for TT, and 50\% for CC in controls; $40.5 \%$ for CT, 5.4\% for 
TABLE 2: Distribution of genotype and alleles frequencies of VDR SNPs in neuro-Behçet's disease and control subjects.

\begin{tabular}{|c|c|c|c|}
\hline & Controls $n(\%)$ & Neuro-Behçet's & $p$ value \\
\hline \multicolumn{4}{|c|}{ ApaI genotype } \\
\hline $\mathrm{AC}$ & $10(33.3)$ & $9(42.9)$ & 0.489 \\
\hline AA & $13(43.3)$ & $7(33.3)$ & 0.472 \\
\hline CC & $7(23.4)$ & $5(23.8)$ & 0.969 \\
\hline \multicolumn{4}{|l|}{ HWE } \\
\hline$\chi^{2}$ & 2.80 & 0.382 & \\
\hline$p$ value & 0.0942 & 0.536 & \\
\hline \multicolumn{4}{|l|}{ ApaI alleles } \\
\hline A & $36(60)$ & $23(54.8)$ & \\
\hline $\mathrm{C}$ & $24(40)$ & $19(45.2)$ & 0.59 \\
\hline \multicolumn{4}{|l|}{ TaqI genotype } \\
\hline CT & $11(36.7)$ & $10(47.6)$ & 0.434 \\
\hline TT & $13(43.3)$ & $8(38.1)$ & 0.708 \\
\hline $\mathrm{CC}$ & $6(20)$ & $3(14.3)$ & 0.598 \\
\hline \multicolumn{4}{|l|}{ HWE } \\
\hline$\chi^{2}$ & 1.511 & 0.0019 & \\
\hline$p$ value & 0.218 & 0.96 & \\
\hline \multicolumn{4}{|l|}{ TaqI alleles } \\
\hline C & $23(38.3)$ & $16(38.1)$ & \\
\hline $\mathrm{T}$ & $37(61.7)$ & $26(61.9)$ & 0.98 \\
\hline \multicolumn{4}{|c|}{ FokI genotype } \\
\hline CT & $12(40)$ & $7(33.3)$ & 0.628 \\
\hline $\mathrm{TT}$ & $15(50)$ & $13(61.9)$ & 0.400 \\
\hline $\mathrm{CC}$ & $3(10)$ & $1(4.8)$ & 0.493 \\
\hline \multicolumn{4}{|l|}{ HWE } \\
\hline$\chi^{2}$ & 0.068 & 0.0021 & \\
\hline$p$ value & 0.794 & 0.96 & \\
\hline \multicolumn{4}{|l|}{ FokI alleles } \\
\hline $\mathrm{T}$ & $42(70)$ & $33(78.6)$ & \\
\hline $\mathrm{C}$ & $18(30)$ & $9(21.4)$ & 0.33 \\
\hline
\end{tabular}

Differences were considered statistically significant at a $p$ value $<0.05$.

TT, and $54.1 \%$ for CC in patients with $\mathrm{BD}$; and $33.3 \%$ for CT, $4.8 \%$ for TT, and $61.9 \%$ for CC in patients with NBD (Tables 1 and 2). The allelic and genotype distributions of FokI polymorphisms were not different $(p>0.05)$.

Comparing the genotype and alleles frequencies of SNPs (TaqI and FokI) in all disease patients (BD + NBD) compared to controls showed no difference $(p>0.05)$ as summarized in Table 3.

\section{Discussion}

In this study we aimed to demonstrate any association or susceptibility between VDR gene polymorphisms and Behçet's disease group consisting of patients with neuroBehçet's and Behçet's disease.

Many studies investigated polymorphisms of the VDR gene in various diseases like osteoporosis, cancer, type 1 diabetes, psoriasis, and urolithiasis worldwide and also in Turkish population.
TABLE 3: Distribution of genotype and alleles frequencies of VDR SNPs in all patients (Behçet's disease and neuro-Behçet's disease) and control subjects.

\begin{tabular}{|c|c|c|c|}
\hline & Controls $n(\%)$ & All patients & $p$ value \\
\hline \multicolumn{4}{|c|}{ ApaI genotype } \\
\hline $\mathrm{AC}$ & $10(33.3)$ & $24(42.9)$ & 0.389 \\
\hline $\mathrm{AA}$ & $13(43.3)$ & $13(23.2)$ & 0.053 \\
\hline $\mathrm{CC}$ & $7(23.4)$ & 19 (33.9) & 0.308 \\
\hline \multicolumn{4}{|l|}{ HWE } \\
\hline$\chi^{2}$ & 2.80 & 0.989 & \\
\hline$p$ value & 0.0942 & 0.319 & \\
\hline \multicolumn{4}{|l|}{ ApaI alleles } \\
\hline A & $36(60)$ & $50(44.6)$ & \\
\hline $\mathrm{C}$ & $24(40)$ & $62(55.4)$ & 0.05 \\
\hline \multicolumn{4}{|l|}{ TaqI genotype } \\
\hline $\mathrm{CT}$ & $11(36.7)$ & $24(41.4)$ & 0.669 \\
\hline TT & $13(43.3)$ & $27(46.6)$ & 0.774 \\
\hline CC & $6(20)$ & 7 (12.1) & 0.320 \\
\hline \multicolumn{4}{|l|}{ HWE } \\
\hline$\chi^{2}$ & 1.511 & 0.213 & \\
\hline$p$ value & 0.218 & 0.643 & \\
\hline \multicolumn{4}{|l|}{ TaqI alleles } \\
\hline C & $23(38.3)$ & $38(32.8)$ & \\
\hline $\mathrm{T}$ & $37(61.7)$ & $78(67.2)$ & 0.46 \\
\hline \multicolumn{4}{|l|}{ FokI genotype } \\
\hline $\mathrm{CT}$ & $12(40)$ & $22(37.9)$ & 0.85 \\
\hline TT & $15(50)$ & $33(56.9)$ & 0.538 \\
\hline $\mathrm{CC}$ & $3(10)$ & $3(5.2)$ & 0.394 \\
\hline \multicolumn{4}{|l|}{ HWE } \\
\hline$\chi^{2}$ & 0.068 & 0.074 & \\
\hline$p$ value & 0.794 & 0.785 & \\
\hline \multicolumn{4}{|l|}{ FokI alleles } \\
\hline $\mathrm{T}$ & $42(70)$ & $88(75.8)$ & \\
\hline $\mathrm{C}$ & $18(30)$ & $28(24.2)$ & 0.40 \\
\hline
\end{tabular}

There are only three publications exploring the VDR polymorphisms in Behçet's disease. One of those was performed in Iranian Azeri population and the remaining two were performed in Tunisian population. The Iranian study detected that the only significant difference was found for FokI polymorphism in Behçet's disease, and the f allele was also high in those patients [22]. One Tunisian study stated that TaqI and ApaI polymorphisms might be modestly implicated in $\mathrm{BD}$ pathogenesis [23]; but the other study suggested that FokI $\mathrm{F}$ allele and F/F genotype associate with $\mathrm{BD}$ and that especially FokI polymorphism is associated with vascular manifestations [24].

Although studies investigating VDR SNPs in Behçet's disease are very few, many studies focusing on Turkish population were performed in various diseases.

Bone mineral density is one of the hottest investigation topics of VDR gene polymorphisms. In a study by Kurt et al., it was proved that VDR FokI "FF" genotype constituted 
TABLE 4: Comparison of our results of alleles frequencies obtained in the control group with other publications performed in Turkish population.

\begin{tabular}{|c|c|c|c|c|c|c|c|c|c|}
\hline & & Our results & $\begin{array}{c}\text { Gunes et al. } \\
{[36]} \\
n=150\end{array}$ & $\begin{array}{c}\text { Dayangac- } \\
\text { Erden et al. } \\
\quad[34] \\
n=100\end{array}$ & $\begin{array}{c}\text { Toptaş et al. } \\
{[33]} \\
n=122\end{array}$ & $\begin{array}{c}\text { Gogas Yavuz } \\
\text { et al. }[26] \\
n=134\end{array}$ & $\begin{array}{c}\text { Buyru et al. } \\
\quad[32] \\
n=27\end{array}$ & $\begin{array}{c}\text { Cakir et al. } \\
{[37]} \\
n=70\end{array}$ & $\begin{array}{c}\text { Kilıç et al. [41] } \\
\quad n=96\end{array}$ \\
\hline ApaI & $\mathrm{A}$ & 0.60 & 0.37 & 0.57 & - & 0.65 & - & 0.614 & 0.54 \\
\hline rs7975232 & $\mathrm{C}$ & 0.40 & 0.63 & 0.425 & - & 0.35 & - & 0.386 & 0.46 \\
\hline FokI & $\mathrm{T}$ & 0.70 & - & 0.73 & 0.717 & 0.84 & - & 0.736 & 0.68 \\
\hline $\begin{array}{l}\text { rs2228570 } \\
\text { rs10735810 }\end{array}$ & $\mathrm{C}$ & 0.30 & - & 0.27 & 0.283 & 0.16 & - & 0.264 & 0.32 \\
\hline TaqI & A & 0.62 & 0.65 & 0.595 & 0.731 & 0.65 & 0.615 & 0.65 & 0.65 \\
\hline rs731236 & $\mathrm{C}$ & 0.38 & 0.35 & 0.405 & 0.273 & 0.35 & 0.384 & 0.35 & 0.35 \\
\hline $\begin{array}{l}\text { Significancy } \\
\text { in disease }\end{array}$ & & $\begin{array}{l}\text { No significancy } \\
\text { in Behçet's and } \\
\text { neuro-Behçet's } \\
\text { disease }\end{array}$ & $\begin{array}{c}\text { No } \\
\text { significancy } \\
\text { in urolithiasis }\end{array}$ & $\begin{array}{c}\text { TaqI } \\
\text { in psoriasis }\end{array}$ & $\begin{array}{c}\text { No } \\
\text { significancy in } \\
\text { brain cancer }\end{array}$ & $\begin{array}{c}\text { No } \\
\text { significancy in } \\
\text { type } 1 \text { diabetes }\end{array}$ & $\begin{array}{c}\text { No } \\
\text { significancy in } \\
\text { breast cancer }\end{array}$ & $\begin{array}{l}\text { No } \\
\text { significancy in } \\
\text { nephrolithiasis }\end{array}$ & $\begin{array}{c}\text { No significancy } \\
\text { in atopic } \\
\text { dermatitis }\end{array}$ \\
\hline
\end{tabular}

risk for lower bone mineral density (BMD) in Turkish postmenopausal women [25]. VDR gene polymorphisms, BsmI, FokI, ApaI, and TaqI were not found to influence the bone metabolism in postmenopausal Turkish women and in a similar group with additional type 1 diabetes [26, 27]. A Turkish study performed in 2009 reported that the distribution of VDR ApaI genotype was similar in osteoporotic, osteopenic, and postmenopausal healthy women [28]. Some studies focused on the Turkish immigrants in Germany in cases with or without additional diseases like diabetes. FokI FF genotype was found to be significantly more prevalent among the Turkish women and Ff-genotyped immigrants showed significantly decreased BMD [29]. Also another study investigating a similar immigrant Turkish population showed that FokI Ff was an important factor for the risk detection for osteoporosis in females [30]. A study performed in Polish patients with systemic lupus (SLE) showed no difference in BsmI polymorphism [31].

The SNPs investigated in our study (FokI (rs10735810), TaqI (rs731236), and ApaI (rs7975232)) have been shown to some extent to be associated with different diseases in the Turkish population compared to control subjects.

These alleles of the SNPs in our control group were similar to those of other studies in the Turkish population (Table 4). For example, a study investigating VDR TaqI and BsmI alleles and the genotype frequencies in female breast cancer patients showed similar results to their control group [32]. Another study suggesting that the only VDR FokI ff genotype was significantly increased in meningioma patients (15.9\%) compared with controls $(2.5 \%)$ and carriers of FokI ff genotype had a 6.47-fold increased risk for meningioma development also showed similar alleles frequency in the control group [33]. The same SNPs were also studied in Turkish patients with psoriasis and healthy controls. Dayangac-Erden et al. demonstrated that VDR gene TaqI polymorphism is associated with familial psoriasis in Turkish population with similar SNP frequencies in their control group [34]. The roles of VDR polymorphisms were also investigated in urolithiasis and nephrolithiasis. Goknar et al. demonstrated that the BsmI and TaqI VDR genotypes may be candidate genes causing infantile urolithiasis [35]. But another study showed that none of the VDR ApaI, BsmI, and TaqI polymorphisms created any significant risk for urolithiasis [36]. In a study by Cakir et al., only " $\mathrm{B}$ " allele was detected to increase the risk of nephrolithiasis 1.5 -fold in 98 patients with calcium oxalate kidney stones [37].

Our results showed no association between the VDR polymorphisms including FokI (rs2228570) and TaqI (rs731236) and patients with neuro-Behçet's $(n=21)$ and Behçet's disease $(n=37)$ compared to healthy controls ( $n=30)$. Only the frequency of ApaI A allele in control is higher than that in $\mathrm{BD}(60 \%$ versus $38.5 \%$; $p=0.014)$, but this result was not considered significant because of the small sample size in our study. This difference between the mentioned studies and our results may be due to group size and ethnicity.

\section{Conclusions}

In conclusion, there are many associations between VDR polymorphisms and several diseases; but in our study we were not able to show any relationship between VDR SNPs (FokI (rs2228570) (rs10735810) and TaqI (rs731236)) and Behçet's and neuro-Behçet's disease in Turkish population. ApaI (rs7975232) A allele seems to be protective in BD, but, because of the small sample size in our study, we are not able to conclude that there is any relationship between ApaI A allele and BD. However, future studies with larger patients' numbers may show differences between the abovementioned polymorphisms and Behçet's disease, taking in account that there was no significant association between VDR SNPs and BD in Turkish, Japanese, and Chinese populations shown by several GWAS studies performed [38-40].

\section{Competing Interests}

The authors declare that there is no conflict of interests regarding the publication of this paper. 


\section{References}

[1] H. Behçet, "Uber rezidivierende aphthouse durch ein virus verursachte Geschwuere am Mund, am Auge und an den Genitalien," Dermatologische Wochenschrift, vol. 105, pp. 11521157, 1937.

[2] A. Gül, "Pathogenesis of behçet's disease: autoinflammatory features and beyond," Seminars in Immunopathology, vol. 37, no. 4, pp. 413-418, 2015.

[3] D. McGonagle and M. F. McDermott, "A proposed classification of the immunological diseases," PLoS Medicine, vol. 3, no. 8, pp. 1242-1248, 2006.

[4] G. Akman-Demir, P. Serdaroglu, and B. Tasçi, "Clinical patterns of neurological involvement in Behçet's disease: evaluation of 200 patients," Brain, vol. 122, no. 11, pp. 2171-2182, 1999.

[5] S. Hirohata, "Histopathology of central nervous system lesions in Behçet's disease," Journal of the Neurological Sciences, vol. 267, no. 1-2, pp. 41-47, 2008.

[6] K. Hamzaoui, I. B. Dhifallah, E. Karray, F. H. Sassi, and A. Hamzaoui, "Vitamin D modulates peripheral immunity in patients with Behçet's disease," Clinical and Experimental Rheumatology, vol. 28, no. 4, pp. S50-S57, 2010.

[7] S. Karatay, K. Yildirim, A. Karakuzu et al., "Vitamin D status in patients with Behcet's disease," Clinics, vol. 66, no. 5, pp. 721-723, 2011.

[8] H. F. DeLuca, "Overview of general physiologic features and functions of vitamin D," The American Journal of Clinical Nutrition, vol. 80, no. 6, pp. 1689S-1696S, 2004.

[9] J. M. Lemire, J. S. Adams, R. Sakai, and S. C. Jordan, "1 alpha,25-dihydroxyvitamin D3 suppresses proliferation and immunoglobulin production by normal human peripheral blood mononuclear cells," The Journal of Clinical Investigation, vol. 74, no. 2, pp. 657-661, 1984.

[10] D. M. Provvedini and S. C. Manolagas, " $1 \alpha, 25-$ dihydroxyvitamin D3 receptor distribution and effects in subpopulations of normal human T lymphocytes," Journal of Clinical Endocrinology and Metabolism, vol. 68, no. 4, pp. 774-779, 1989.

[11] V. Mocanu, T. Oboroceanu, and F. Zugun-Eloae, "Current status in vitamin $\mathrm{D}$ and regulatory $\mathrm{T}$ cells-immunological implications," Revista Medico-Chirurgicala a Societatii de Medici si Naturalisti din Iasi, vol. 117, no. 4, pp. 965-973, 2013.

[12] Y. Tian, C. Wang, Z. Ye, X. Xiao, A. Kijlstra, and P. Yang, "Effect of 1,25-dihydroxyvitamin D3 on Th17 and Th1 response in patients with Behçet's disease," Investigative Ophthalmology \& Visual Science, vol. 53, no. 10, pp. 6434-6441, 2012.

[13] M. Can, M. Gunes, O. A. Haliloglu et al., "Effect of vitamin D deficiency and replacement on endothelial functions in Behçet's disease," Clinical and Experimental Rheumatology, vol. 30, no. 3, supplement 72, pp. S57-S61, 2012.

[14] J. E. Do, S. Y. Kwon, S. Park, and E.-S. Lee, "Effects of vitamin D on expression of Toll-like receptors of monocytes from patients with Behçet's disease," Rheumatology, vol. 47, no. 6, pp. 840-848, 2008.

[15] S. E. Taymans, S. Pack, E. Pak et al., "The human vitamin $\mathrm{D}$ receptor gene (VDR) is localized to region 12cen-q12 by fluorescent in situ hybridization and radiation hybrid mapping: genetic and physical VDR map," Journal of Bone and Mineral Research, vol. 14, no. 7, pp. 1163-1166, 1999.

[16] Y. Xu, B. He, Y. Pan et al., "Systematic review and meta-analysis on vitamin D receptor polymorphisms and cancer risk," Tumor Biology, vol. 35, no. 5, pp. 4153-4169, 2014.
[17] D. Lykouras, F. Sampsonas, A. Kaparianos, K. Karkoulias, G. Tsoukalas, and K. Spiropoulos, "Human genes in TB infection: their role in immune response," Monaldi Archives for Chest Disease, vol. 69, no. 1, pp. 24-31, 2008.

[18] L. Rolf, A.-H. Muris, R. Hupperts, and J. Damoiseaux, "Vitamin D effects on B cell function in autoimmunity," Annals of the New York Academy of Sciences, vol. 1317, no. 1, pp. 84-91, 2014.

[19] K. Tizaoui, A. Berraies, B. Hamdi, W. Kaabachi, K. Hamzaoui, and A. Hamzaoui, "Association of vitamin D receptor gene polymorphisms with asthma risk: systematic review and updated meta-analysis of case-control studies," Lung, vol. 192, no. 6, pp. 955-965, 2014.

[20] T. K. Wöbke, B. L. Sorg, and D. Steinhilber, "Vitamin D in inflammatory diseases," Frontiers in Physiology, vol. 5, article 244, 2014.

[21] F. Davatchi, S. Assaad-Khalil, K. T. Calamia et al., "The International Criteria for Behçet's Disease (ICBD): a collaborative study of 27 countries on the sensitivity and specificity of the new criteria," Journal of the European Academy of Dermatology and Venereology, vol. 28, no. 3, pp. 338-347, 2014.

[22] S. Kolahi, A. Khabbazi, H. Khodadadi et al., "Vitamin D receptor gene polymorphisms in Iranian Azary patients with Behçet's disease," Scandinavian Journal of Rheumatology, vol. 44, no. 2, pp. 163-167, 2015.

[23] K. Tizaoui, W. Kaabachi, M. Ouled Salah, A. Ben Amor, A. Hamzaoui, and K. Hamzaoui, "Vitamin D receptor TaqI and ApaI polymorphisms: a comparative study in patients with Behçet's disease and Rheumatoid arthritis in Tunisian population," Cellular Immunology, vol. 290, no. 1, pp. 66-71, 2014.

[24] E. F. Karray, I. Ben Dhifallah, K. Ben Abdelghani et al., "Associations of vitamin D receptor gene polymorphisms FokI and BsmI with susceptibility to rheumatoid arthritis and Behçet's disease in Tunisians," Joint Bone Spine, vol. 79, no. 2, pp. 144-148, 2012.

[25] O. Kurt, H. Yilmaz-Aydogan, M. Uyar, T. Isbir, M. F. Seyhan, and A. Can, "Evaluation of ER $\alpha$ and VDR gene polymorphisms in relation to bone mineral density in Turkish postmenopausal women," Molecular Biology Reports, vol. 39, no. 6, pp. 67236730, 2012.

[26] D. Gogas Yavuz, L. Keskin, S. Kıyıc1 et al., "Vitamin D receptor gene BsmI, FokI, ApaI, TaqI polymorphisms and bone mineral density in a group of Turkish type 1 diabetic patients," Acta Diabetologica, vol. 48, no. 4, pp. 329-336, 2011.

[27] T. Yoldemir, D. G. Yavuz, G. Anik, N. Verimli, and M. Erenus, "Vitamin D receptor gene polymorphisms in a group of postmenopausal Turkish women: association with bone mineral density," Climacteric, vol. 14, no. 3, pp. 384-391, 2011.

[28] U. Dundar, M. Solak, V. Kavuncu et al., "Evidence of association of Vitamin D receptor Apa I gene polymorphism with bone mineral density in postmenopausal women with osteoporosis," Clinical Rheumatology, vol. 28, no. 10, pp. 1187-1191, 2009.

[29] Y. Tastan, P. H. Kann, H. Tinneberg, P. Hadji, U. MüllerLadner, and U. Lange, "Low bone mineral density and vitamin $\mathrm{d}$ deficiency correlated with genetics and other bone markers in female Turkish immigrants in Germany," Clinical Rheumatology, 2016.

[30] I. H. Tarner, M. Z. Erkal, B. M. Obermayer-Pietsch et al., "Osteometabolic and osteogenetic pattern of Turkish immigrants in Germany," Experimental and Clinical Endocrinology and Diabetes, vol. 120, no. 9, pp. 517-523, 2012.

[31] B. Kaleta, J. Bogaczewicz, E. Robak et al., "Vitamin D receptor gene BsmI polymorphism in Polish patients with systemic 
lupus erythematosus," ISRN Endocrinology, vol. 2013, Article ID 427818, 5 pages, 2013.

[32] N. Buyru, A. Tezol, E. Yosunkaya-Fenerci, and N. Dalay, "Vitamin D receptor gene polymorphisms in breast cancer," Experimental and Molecular Medicine, vol. 35, no. 6, pp. 550555, 2003.

[33] B. Toptaş, A. M. Kafadar, C. Cacina et al., "The vitamin D receptor (VDR) gene polymorphisms in Turkish brain cancer patients," BioMed Research International, vol. 2013, Article ID 295791, 6 pages, 2013.

[34] D. Dayangac-Erden, A. Karaduman, and H. Erdem-Yurter, "Polymorphisms of vitamin D receptor gene in Turkish familial psoriasis patients," Archives of Dermatological Research, vol. 299, no. 10, pp. 487-491, 2007.

[35] N. Goknar, F. Öktem, E. Torun et al., "The role of vitamin D receptor gene polymorphisms in Turkish infants with urolithiasis," Renal Failure, vol. 38, no. 4, pp. 545-551, 2016.

[36] S. Gunes, C. Y. Bilen, N. Kara, R. Asci, H. Bagci, and A. F. Yilmaz, "Vitamin D receptor gene polymorphisms in patients with urolithiasis," Urological Research, vol. 34, no. 1, pp. 47-52, 2006.

[37] O. O. Cakir, A. Yilmaz, E. Demir, K. Incekara, M. O. Kose, and N. Ersoy, "Association of the BsmI, ApaI, TaqI, Tru9I and FokI polymorphisms of the vitamin D receptor gene with nephrolithiasis in the Turkish population," Urology Journal, vol. 13, no. 1, pp. 2509-2518, 2016.

[38] E. F. Remmers, F. Cosan, Y. Kirino et al., "Genome-wide association study identifies variants in the MHC class I, IL10, and IL23R-IL12RB2 regions associated with Behçet's disease," Nature Genetics, vol. 42, no. 8, pp. 698-702, 2010.

[39] Y. Kirino, G. Bertsias, Y. Ishigatsubo et al., "Genome-wide association analysis identifies new susceptibility loci for Behçet's disease and epistasis between HLA-B ${ }^{*} 51$ and ERAP1," Nature Genetics, vol. 45, no. 2, pp. 202-207, 2013.

[40] S. Hou, Z. Yang, L. Du et al., "Identification of a susceptibility locus in STAT4 for Behçet's disease in Han Chinese in a genome-wide association study," Arthritis \& Rheumatism, vol. 64, no. 12, pp. 4104-4113, 2012.

[41] S. Kılıç, F. Sılan, M. M. Hiz, S. Işık, Z. Ögretmen, and Ö. Özdemir, "Vitamin D receptor gene BSMI, FOKI, APAI, and TAQI polymorphisms and the risk of atopic dermatitis," Journal of Investigational Allergology and Clinical Immunology, vol. 26, no. 2, pp. 106-110, 2016. 


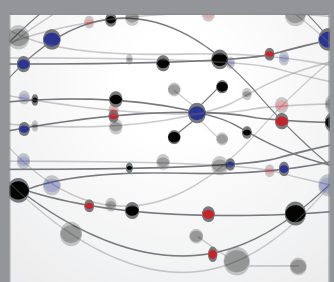

The Scientific World Journal
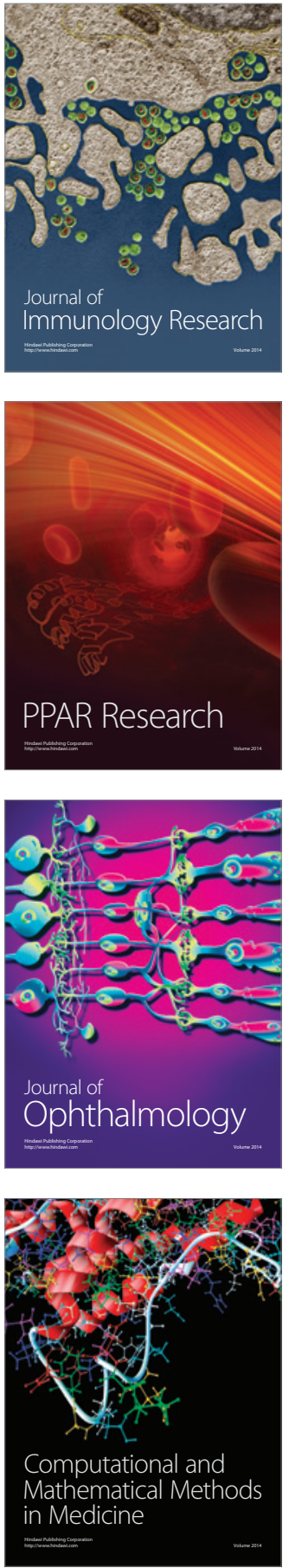

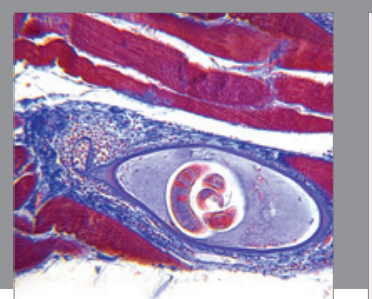

Gastroenterology Research and Practice

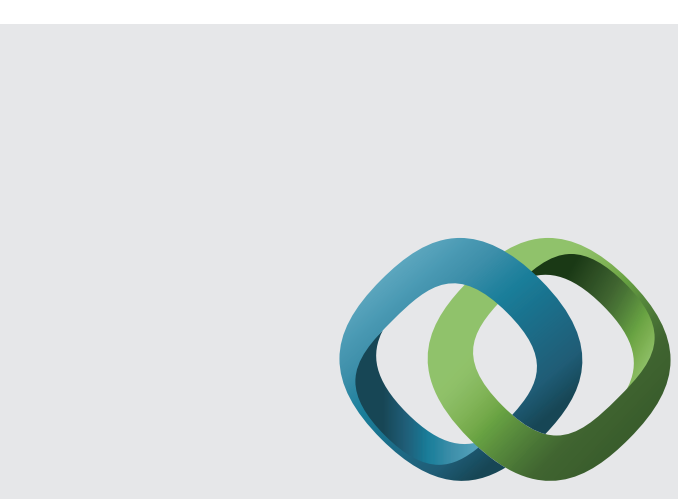

\section{Hindawi}

Submit your manuscripts at

http://www.hindawi.com
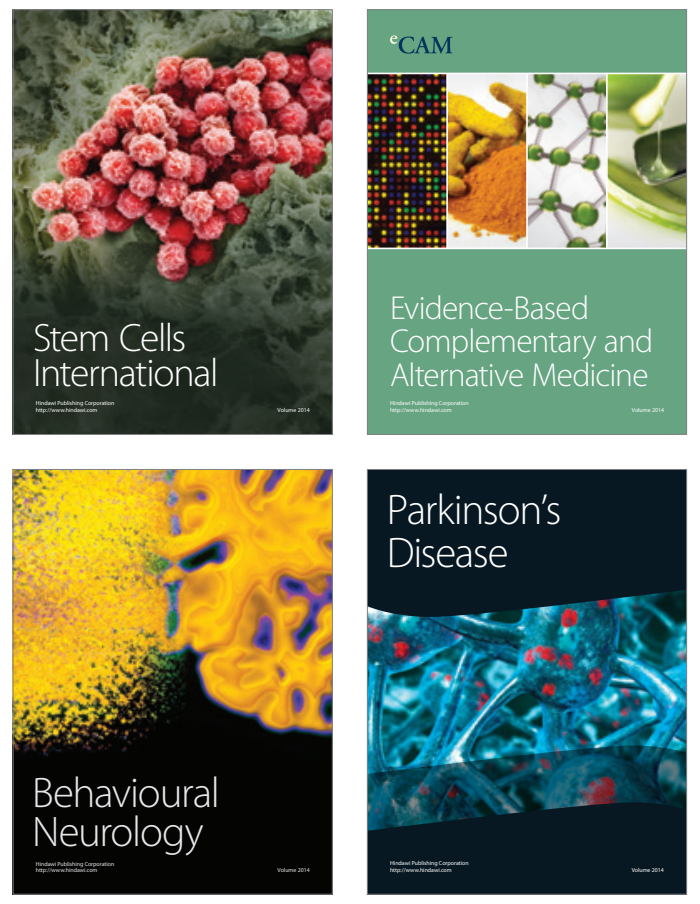
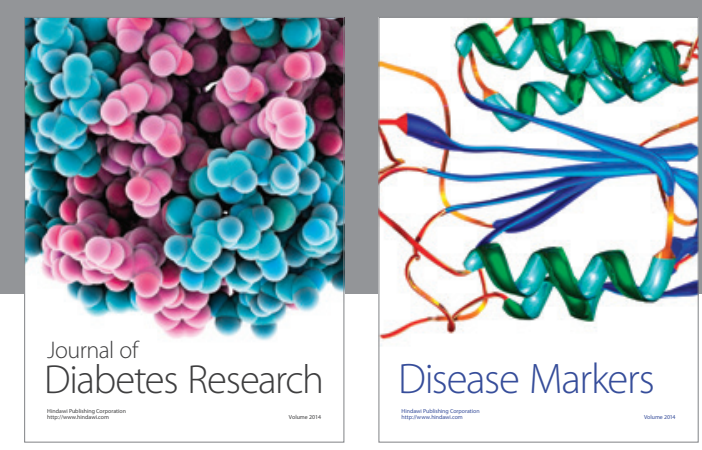

Disease Markers
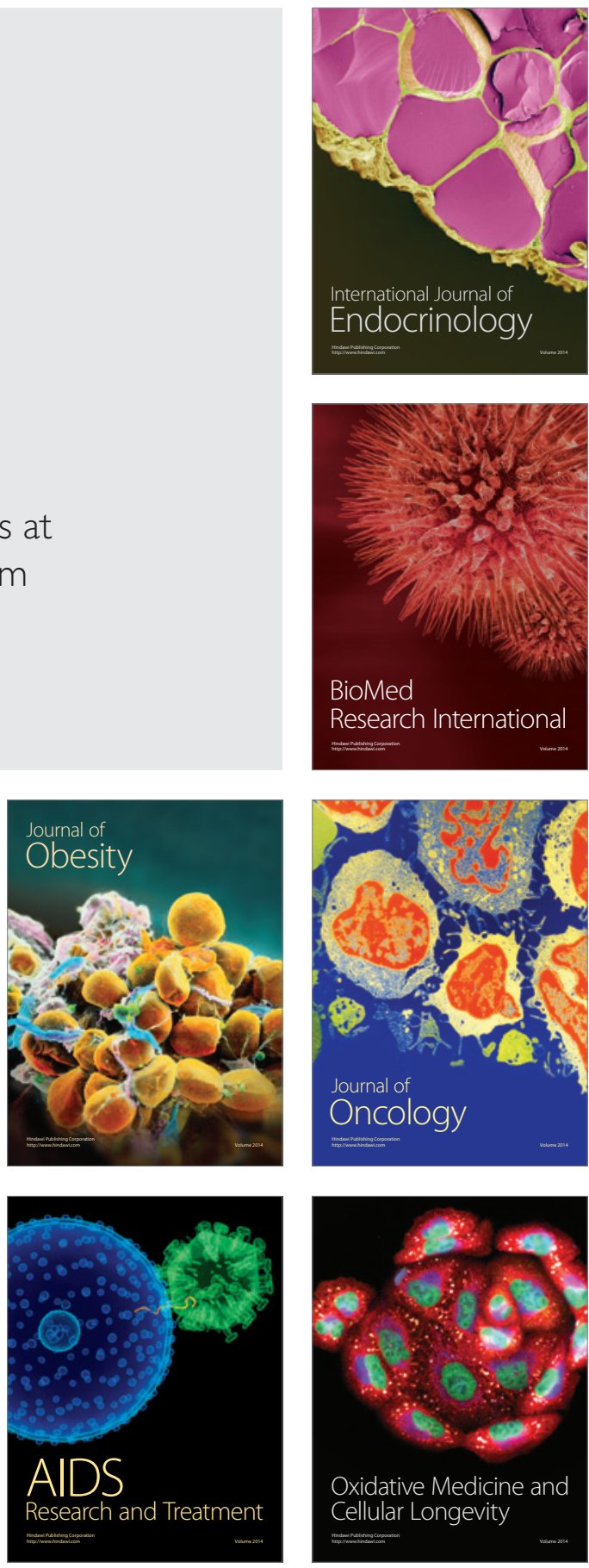